\title{
Financial Needs of Internationalized Firms
}

\author{
Federica Sist ${ }^{1}$ \\ ${ }^{1}$ LUMSA University, Rome, Italy \\ Correspondence: Federica Sist, LUMSA University, Rome 2200197, Italy. E-mail: federica.sist@gmail.com \\ Received: April 8, 2014 \\ Accepted: September 29, $2014 \quad$ Online Published: October 13, 2014 \\ doi:10.5430/ijfr.v5n4p171 \\ URL: http://dx.doi.org/10.5430/ijfr.v5n4p171
}

\begin{abstract}
This paper is a conceptual work on financial needs generated by the internationalization process of firms, especially non-large ones, in their life cycle. The forms of internationalization considered are trade (export and import) and foreign direct investment (FDI).

A careful analysis of the literature reveals a dearth of research on this specific topic; in fact, the financial side of international business theory is poorly treated and the study of financial needs is often included in other types of financial inquiries (e.g., financial benefits, financial constraints, raising capital or credit abroad). The conceptual analysis is developed in the phases of a generic life cycle to understand whether the financial requirements for specific international actions are amplified or moderated. In the first phase of the cycle, the financial needs are amplified with respect to type of strategy chosen; the growth stage implies a continual need for cash flows; and the financial conditions of the maturity phase tend to moderate fund demands. This study is the first to explain the effects of internationalization actions on financial needs.
\end{abstract}

Keywords: financial need, internationalization, corporate finance finance

\section{Introduction}

The impact of the internationalization process on a firm's financial management requires finance-specific considerations of foreign transactions and investments that do not exist in domestic markets (Remmers, 2004). Even if the interaction between the internationalization process and finance exists, it is relatively unexplored (Filatotchev, Piesse, 2009). The financial issues studied in international behaviors of firms usually involve corporate governance, risks, financial market segmentation, performance of multinational corporations (MNCs), and cash management.

Access to financing is determinant in the choice of firm for export (Barman, Hericourt, 2008) and this has been explored in several studies, but often only from the perspective of the constraints firms face, especially small firms (Tannaus, 1997; Gottfries, 2002; Maurel, Viviani, 2010; De Maeseneire, Claeys, 2011; Arndt, Buch, Mattes, 2012). Some researchers have argued that the choice of debt/equity swap or equity listing in foreign equity markets is critical for foreign direct investment (FDI) success (Oxelheim, Randoy, Stonehill, 2001).

The financial factors of cross-border investments have to be explicated to understand their dimensions (Forssbaeck, Oxelheim, 2008). Therefore, it is important to begin with the first step of financial evaluation, which is the financial needs generated by operating abroad. To date, no theory has tried to explain the dynamics of financial requirements associated with the internationalization process.

The aim of this work is to analyze financial needs generated by the internationalization of firms, especially micro, small and medium firms, without applying a specific theory because the issues are transverse and these needs arise independent of the drivers of internationalization.

The support/model used to classify the needs is the life cycle of the firm so as to conceptualize the dynamics of financial requirements with respect to the business and the effects of international actions such as export and FDI. A study of this side of financial management contributes to several disciplines and research fields. Firms themselves can integrate the traditional analysis into planning financial resources, strategies, and revenues. They can also use the analysis to understand which stage of their own life cycle is most appropriate for expanding the business or production over the borders. Financial institutions can benefit from this paper by using it to review services for firms that are foreign market oriented, advance the demands of financial support, and evaluate risk with respect to stage of life. The behavioral interactions of financial institutions and firms in their internationalization choices reveals how relationships between banks and firms encourage manufacturing firms' production internationalization (De Bonis, Ferri, Rotondi, 2010), as the internationalization of firms pushes banks to develop internationalization strategies to 
follow customers abroad. When researchers enhanced the territoriality characteristic of types of banks as cooperatives (BCCs), they suggested the interesting link between non-large firms and BCCs; they have a strong relationship that can be tapped to create a virtuous circle for both in conducting business abroad. Analysis of this phenomenon is surely necessary to pass through to understanding how the micro, small, and medium-sized firms (MSMs), BCCs' customers, internationalize and what they need to export or develop FDI.

The following section explains how Italian MSM firms internationalize and, the preceding part on the analysis of financial needs for international activities in the business cycle is about the use of financial services by firms in international activity. After the analysis, we conclude with a discussion of main results and suggestions for related research on this topic.

\section{Internationalization of MSM Firms and Financial Effects}

The international relationships among firms can differ in trade and productive internationalization, with several types of business approaches in both areas.

The different ways of internationalizing in trade reflect the international relationships that the firm has developed. The export will assume different forms with respect to a different presence in the destination country, from an absence to a strong presidio (Chiarvesio et al., 2006). In the first case, trade takes the form of exchange; in the second, the firm has a network of retail outlets and control of the target market is paramount. Imports are the result of a supply chain internationally organized and obtained after vertical integration or just the purchase of products or commodities from foreign suppliers.

Production abroad can affect the whole chain or just a few phases; it can be pursued for several reasons, including imperfections of markets, accessibility to resources, and increased sales. The modalities for producing part, or all, of the products are developed by the firm itself or through agreements with partners. Partners can come from the country of origin, the destination country, or a third country; the choice is critical for the success of operations. This necessitates wider planning to organize the financial side of operations and establish control by the partners.

Some researchers have noted financial internationalization when a firm locates foreign financiers, for both equity and debt; usually these firms are large and have strong international relationships (Urionabarrenetxe \& Rodríguez Castellanos, 2009).

All international relationships imply different levels of involvement of firms in the control of operations and financial management. These levels can be classified into exports with low presidio and those with high presidio. Exports with low presidio will be less binding in terms of finance and the power outlined in the contract is low, but the firm will begin to learn international financial management. Exports with high presidio require moderate involvement and the financial management is more sophisticated. However, with both, the main question is the timing of return cash flow, and this depends on how the product is finished and the amount of the export in total sales. Imports are affected mainly by volatility in the price of commodities and high transaction costs, so financial management uses several techniques to overcome these difficulties. International non-equity alliances, agreements with foreign partners, imply low involvement and are usually designed for supply, for sales, or to begin a relationship with foreign partners to produce. Thus, they require involvement in terms of obligations, but are not so relevant in terms of finance. The forms with stronger engagement are foreign direct investments, building plans, establishment of subsidiaries in the target market alone or in joint venture with a foreign partner, the acquisition of at least $10 \%$ of a foreign firm (whole company or a unit), or achieving partial or total control of a new firm or acquired firms.

Obviously, the general considerations regarding the effects of internationalization are not presented to scholars; they must examine the characteristics of firms. Firms plan the mode and choose the form to develop international relationships by comparing the options with their own features, such as size, property structure, and affiliation with a district (Zahra, 2003; Federico, 2005; Graves \& Thomas, 2008; Zucchella \& Pepe, 2009; Sist, 2010).

\section{Financial Needs}

In this section the aim is to show the results of a survey on which financial services offered by banks are required in different international activities and financial needs by firms (Borghi et al. 2006).

To satisfy the financial needs of liquidity/cash the most required financial services are: credit lines pro-solvendo, especially in the first stage, credit lines pro-soluto, documentary credits, occasionally the confirming. Long-term credit lines (revolving, standby, evergreen, bid line, step-up,...) support the international strategies that imply needs in fixed capital, but as facilities, credit by buyers, documentary credit, confirming and international collaterals. All this services are surely in use in maturity steps and in advanced state of internationalization, that is characterized also by international bank collaterals and the absence of facilities. Anyway in the growth are not considered aims and the other m-l term credit lines, while the start includes credit lines pro-solvendo and national facilities. If we look at the 
differences in the forms of internationalization using financial services in order a joint venture requires national facilities and international bank collaterals, productive FDIs add other $\mathrm{m}-1$ term credit lines, commercial FDIs needs monetary credits instead of other m-l term credit lines. The export form is different if the good is for consume or instrumental respect to, always, other $\mathrm{m}-\mathrm{l}$ term credit lines. In the case of outsourcing the $\mathrm{m}-\mathrm{l}$ term buyer credit too.

In any case the most required services are the documentary credits and pro-solvendo line credit for different forms of internationalization, except for FDIs. Several consideration can be developed on these results, but the consequent phase should be a second survey on what firms ask and don't find, the match of results will help to understand the gap between what firms ask and what financial system offers. The existence of this gap comes from the idea that some authors believe that banks offer more products than that utilized, and if you speak with entrepreneurs they complain not enough grants for the conditions required or lack of services form banks. Thus which is the problem? The firms are not able to integrate them in its own business administration and/or facing collateral required? Specularly, the banks could offer less standardized services, but more taylor made and as results of frequent survey on the evolution of scenarios, industrial structure, dynamics international markets, ...?

\section{Financial Needs of Internationalized MSM Firms: Discussion}

The international literature on the financial side of international business theory of MSMs is not sufficiently represented in all its own facets; when funding is mentioned, it is usually considered a problem.

The financial needs stream requires deeper examination so that firms and financial institutions can benefit. In fact, financial institutions need to better understand the services offered with respect to the evolution of financial management requirements, while firms need to examine what happens to their financial management with respect to decisions to assume and select strategies.

The financial needs of firms in general depend on a wide array of factors. To predict the dimension of funds requirements, attention must focus on the nature of the business and its stage in the life cycle. Additional factors must be considered for firms involved in international activities.

In international corporate finance, the role played in the supply chain is important additional information (Madura, 2009). The first funder of the trade is often the supplier, who must wait a period before receiving payment from the buyer. This period can be short or long; if it is long, the seller is funding the cycle of export.

In the literature, researchers have argued that internationalization is pursued in sequential stages (Leonidou \& Katsikeas, 1996), born global (Mckinsey et al., 1993; Knight \& Cavusgil, 1996), in eclectic ways (Dunning, 1988), under contingency (Reid, 1983), in networks (Sharma \& Johanson, 1987), and in a holistic manner (Luostarinen, 1979), anyway these information does not change the financial considerations needed.

When the motivation for internationalization is explained by theory as the resource-based view, the institutional view, or by transaction costs, an interaction of the decision to internationalize and financial needs is conceivable, especially for small entities in which financial facilities and constraints influence strategy.

In any case, regardless of whether a firm is first an exporter or a subsidiary owner or a partner in a deal, the aim of this section is to identify the financial effects of these positions in the different stages of the life cycle of a standard firm. (Note 1)

If the firm starts the cross-border activity, and has no relationship in the target country, it faces various issues-the choice of a counterpart or partner, several missions to meet the partner and organize the deals-that must be consistent with regulation and the sales conditions. When the target market is familiar and no-FDI has been conducted (e.g., trade activity, non-equity deals), the entrepreneur may begin to organize the birth of a firm to produce or commercialize, independently or in partnership with local firms. In this second scenario, the skills required to manage the financial aspects are surely greater and they involve hedging risks of insolvency, exchange (if the target country has a different currency from the country of origin), and politics of the target country for exports, but the firm will be learning gradually to address these issues. The surviving firms, in these two phases, will become genuine global firms; their financial needs dimensions imply more sophisticated financial requests in the international markets.

Export activity is linked to current asset management and liquidity, which, as in all firms, is necessary to ensure the process of purchasing, production, and sales, as well as the solvency of the firm. Liquidity is a considerable problem because the cycle of money returned is longer and riskier. The case of FDIs is different, because FDIs are fixed-asset investments and require financial resources over a long period; in fact, the cash flow from investments will be returned over a longer period than the production cycle. In both, the hedge of risks assumes an important role in limiting losses and, consequently, continuing foreign activity. 
The methodology applied involves an empirical analysis of the financial needs of Italian firms with international processes in course or beginning, based on Borghi et al. (2006) and relying on the life cycle graph designed by Gatti and Caselli (2006).

The hypothesis assumed is that firms can internationalize in different stages of their life cycle. Every stage characterizes the financial side of the business with respect to the needs of management and strategies; these needs and strategies mitigate in a few cases and magnify in others the actions settled on with respect to internationalization.

The scenarios imagined are explained for every stage of the life cycle. The financial needs in the start/growth/maturity stages if the firm begins to trade abroad (export, import), develop FDI, and engage in non-equity deals are too complicated for low involvement cataloging, so they will not treated. The design of life cycle for every scenario is helpful to comment the financial effects of international actions.

\begin{tabular}{|c|c|c|}
\hline $\begin{array}{l}\text { Start } \\
\text { High free cash flow needs. } \\
\text { Equity is the principal resource. }\end{array}$ & $\begin{array}{l}\text { Growth } \\
\text { High free cash flow needs, but } \\
\text { revenues is growing. }\end{array}$ & $\begin{array}{l}\text { Maturity } \\
\text { Internal and external resources. }\end{array}$ \\
\hline $\begin{array}{l}\text { Trade in start stage } \\
\text { If the firm } \\
\text { - imports } \Rightarrow>\text { supplier is the } \\
\text { funder, } \\
\text { - exports }=>\text { the fcf needs grows. }\end{array}$ & $\begin{array}{l}\text { Cash flows are from domestic and } \\
\text { foreign sales } \\
\text { Debts are mainly from domestic } \\
\text { market. } \\
\text { Risk is less than in the early trade } \\
\text { stage: low experience. }\end{array}$ & $\begin{array}{l}\text { Its reputation helps to raise less expensive funds } \\
\text { in domestic and global financial market - } \\
\text { experience in foreign trade. }\end{array}$ \\
\hline- & $\begin{array}{l}\text { Trade in growth stage } \\
\text { If exporter, high free cash flow need. } \\
\text { Cash flows are from domestic sales. } \\
\text { Expensive debt from domestic } \\
\text { market. } \\
\text { The risk is still high: no experience. }\end{array}$ & $\begin{array}{l}\text { The free cash flow need is compensated by } \\
\text { positive cash flow generated in this stage from } \\
\text { the business by itself, even if there is not relevant } \\
\text { feedback from the export cycle. } \\
\text { The relevant part of internal resources is no more } \\
\text { engaged in refund debt; moreover, external } \\
\text { resources are not too expensive: } \\
\text { - low experience in foreign trade } \\
\text { - reputation in domestic market acquired. }\end{array}$ \\
\hline- & - & $\begin{array}{l}\text { Trade in maturity stage } \\
\text { The part of cash flow needs to fund } \\
\text { import/export actions is compensated by positive } \\
\text { cash usually generated in this stage. Internal } \\
\text { resources and not too expensive external } \\
\text { resourses: no experiance in foreign trade, but } \\
\text { reputation in domestic market. }\end{array}$ \\
\hline
\end{tabular}

Figure 1. Trade in life cycle: the effects on financial needs 


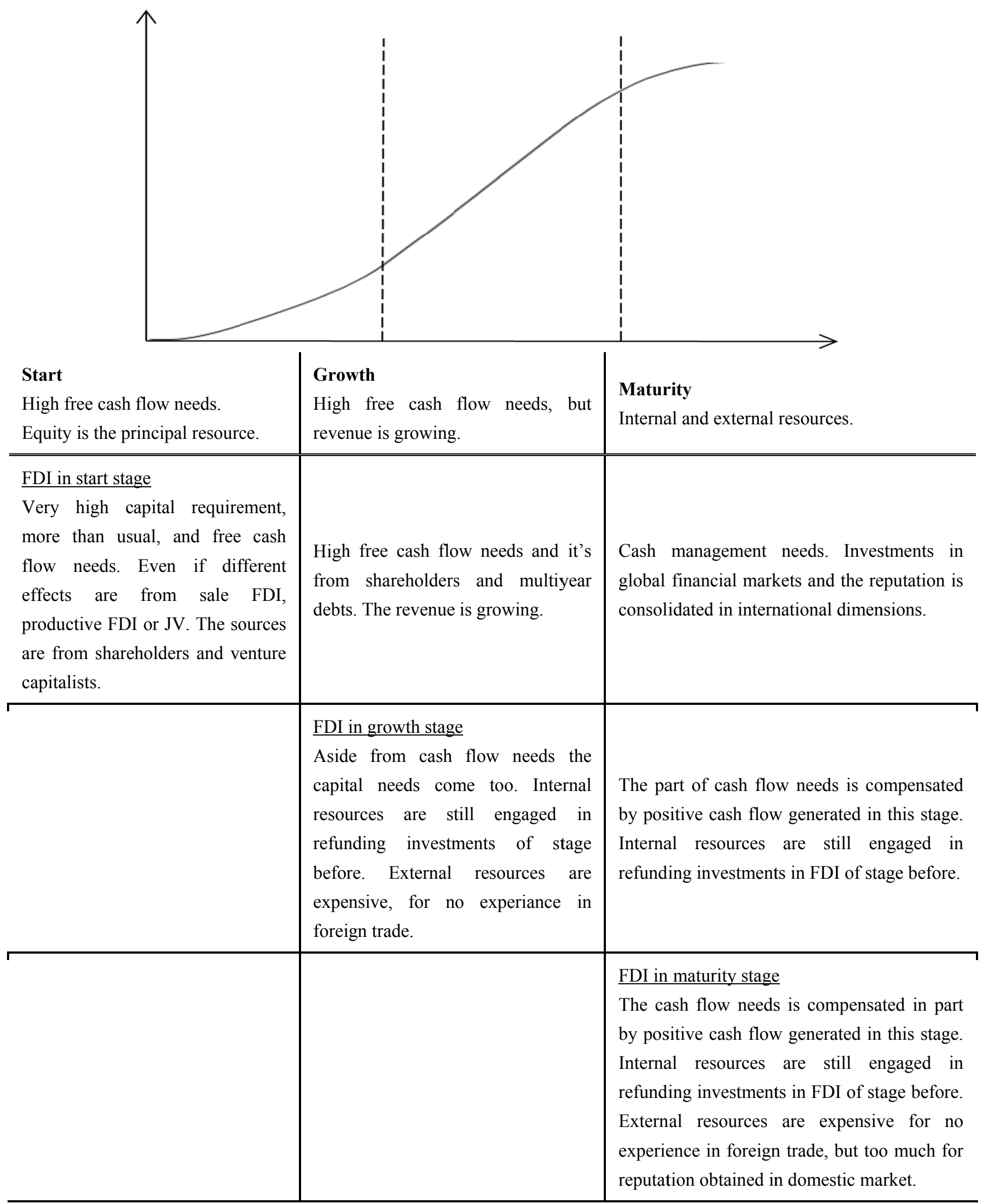

Figure 2. FDI in life cycle: the effects on financial needs 
Both trade and FDI developed in any stage complicate the raising of capital, especially in the beginning phases, and imply a longer feedback in terms of cash flows; financial involvement in the two kinds of internationalization modes means different needs.

At first, the analysis of needs is related to trade (Figure 1), intended as import and export, in stages of the life cycle. Trade activity is the most frequently pursued as the first step in the internationalization process and the easiest tactic for micro and small firms. When trade begins in the start stage, the implications are different if there is a prevalence of import or export. The need, typical of this phase, is capital for investments in facilities of manufacturing firms or for investments in service firms. The cash flow is negative because revenue starts from zero, and the return of positive cash flow from sales abroad is distant-further for instrument goods and closer if consumer goods are exchanged. The raising of capital is conditioned by risk of a new firm, unknown reliability, trading abroad, high cost of starting a business, and financing an export process, among other risks. If firms import instead of export, the involvement is lower because the supplier is most likely financing the process; a problem may arise from variations in the exchange rate if the companies use different currencies. The following stage, growth, is characterized by a return of investment in cash flow from domestic and foreign, if exporter, sales. The revenue increases, but the operating costs and debts absorb positive cash flow until the company arrives to a cash cow scenario. In the last stage, debts are closed or closing and cash flow has begun to be positive. If trade is implemented in the growth stage, the argument is different. The difficulty in financing international projects is always present, so the question of lack of reputation and the need to ask for funds, relative to first step, is in part overcome. The firm still needs cash flow to pay for supply missions or operating expenses because, although in this period the revenue is growing, the firm is repaying debt.

The beginning of trade in maturity appears to imply an easier financial management of needs. The main need for cash flow persists, but it is compensated by the cash flow generated and the reputation (if good) is consolidated, even if the re-styling process of strategies begins.

FDIs require a different analysis (Figure 2), even if the major related need is capital in all stages. In the start stage, firms require capital to start and cash flow; the revenue is zero and the cash flow negative. The capital raised is expensive, inasmuch as financial institutions involved in financing the enterprise perceive it as risky and an international project amplifies this sentiment. The first step for its own nature is characterized by capital need and cash flow, however the realization of investments abroad requires more capital with longer times for returns and, usually, high risk. In commercial FDIs, the problem highlighted is the relevant presence of credit, as in exports. As in the first step, firms demand capital to invest and the cost should be high, but not as high as in the first step when firms ask for capital to invest abroad.

Financial difficulties in implementing FDIs in the second step of the life cycle are smaller. While the revenue is no longer zero and the firm is becoming able to repay debt and to make expenditures, the need for capital persists and the funds are still not from domestic or foreign markets. The capital assumes the form of equity to constitute a joint venture or a branch or simple capital investments. The aims of FDI seem to make no difference in financial needs.

Beginning FDI in the second stage requires lines of credit to fund investments and multi-year debts and the main consequence in the following phase is not having a solid reputation and cash flow to manage the international finances. When FDI is implemented in the maturity stage, the advantage resides in the reputation in the domestic market and a strong financial structure with little indebtedness; the debts necessary to start up have been repaid or are being repaid.

Surely the reasons for international operations, if to acquire advantages in internal or foreign markets, change financial management in terms of a decrease in costs (increase in margin) or increase in sales and the hedging of risks.

The reputation of firms in international markets is central in obtaining grants from financial system; a reputation for reliability must be built. This factor is important because a solid reputation mitigates the risks perceived by financial institutions, even if the balance sheet is always the major determinant in financing. A multinational firm in the maturity stage usually has a solid reputation, and the financial market in which to raise funds and realize cash management is international. When micro, small, and medium-sized firms own international activities, banks develop an analysis of financial resource needs to understand their value and which instruments are helpful for a 
specific activity and obtainable for the characteristics the firm seeks; a "good" reputation can decrease the financial need to repay debts in terms of low interest applied to loans.

Differences in types of financial need with respect to ownership structure were not present in Borghi at al.'s (2006) study; however, differences with respect to size were. Considering that the pecking order model differs with respect to size of firm (Beck, Demirguc-Kunt, Maksimovic, 2008), no- large firms must rely on internal funds or venture capitalists. The most relevant reasons for this are the low propensity toward external funds and the need to ask banks for a loan. This last scenario occurs when the firm is not sufficiently capitalized and/or the investment of the firm is so risky that the collateral offered is not sufficient to secure the loan.

Banks surely prefer to lend funds to finance investments proposed by large firms over small firms. This trend is amplified when the investments to be funded includes projects with cross-border activities such as trade and financial direct investment because the agency costs of lending are high, the collaterals required are major, and the constraints grow. The European industrial structure should suggest cooperation through firms to overcome the strong presence of small and medium firms, but different financial solutions too.

\section{Conclusion}

The lack of studies on financial requirements of firms with trade and FDI developed in different stages of their own life cycle offers several suggestions for future research. This absence prompts to inquire the intuitive ideas on what amplifies capital needs or moderates cash flows when international actions are pursued. The analysis of several strategies of internationalization is developed in different stages of life cycle of the firm, focusing on the effects of financial needs.

Trade without presidio requires fewer financial resources, and easier financial management than that needed for the creation of a presidio and FDIs, which requires capital.

A following paper should analyze the financial effects of crossing the evolution of FDIs and trade consequences.

This paper seeks to change the perspective of business analyses, suggesting that the literature look at businesses integrating international actions as a whole of management. The phenomenon of internationalization by itself makes sense, but branches of management have to include the international financial side of valuing scenarios. In such context the paper wants to point attention in literature on financial topics of international activities.

The main effects of this study would be three. At first, the different approach of scholars in international business, whose will go more in deep analyzing financial side of international operations, recognizing its role of supporting business. The second is the use of the evaluation of which financial consequences could have a strategy pursues during a specific phase of the business by managers and entrepreneurs expanding their business abroad. The third implication is the launch of bases from which to analyze the services offered by banks to their customers, in a second step, and links, in third one, to all those studies in which the authors have tried to understand whether the internationalization of financial systems is a consequence or a cause of customers' internationalization, under the assumption that the bank system is composed by different subjects such as big banks and cooperatives that react in different ways to different relationships, it is relevant in the evolution of financial services offered by banks.

The business cycle, probably, is a very theoretical support, because of changing in scenarios or features of industry of affiliation. When an economic or financial crisis explodes, in some industries, the relative reactions implies changes in strategies in a quick period, but the evaluations based on a plan (even if theoretical as the business cycle) made before will be more accurate. The characteristics of the industries evolve and the cycle will assume many forms and trends, with new born for firm age or markets requirements. The business cycle remains the point of starting the thoughts on strategies and financial needs, whatever the actual cycle is.

\section{Acknowledgement}

Thanks to Prof. Alessandro Carretta, Prof. Oxelheim, the referee and the discussant of annual EIBA Conference 2012 for suggestions proposed.

\section{References}

Arndt, C., Buch, C.M., \& Mattes, A. (2012). Disentangling barriers to internationalization. Canadian Journal of Economics, 45, 41-63. http://dx.doi.org/10.1111/j.1540-5982.2011.01686.x 
Beck, T., Demirguc-Kunt, A., \& Maksimovic, V. (2008). Financing patterns around the world: Are small firms different? Journal of Financial Economics, 8, 467-487. http://dx.doi.org/10.1016/j.jfineco.2007.10.005

Beretta, E., Del Prete, S., \& Federico S. (2004). Internazionalizzazione del sistema bancario e propensione all'export delle province italiane. Economia e diritto del terziario, 3 .

Berman, N., \& Hercourt, J. (2008). Financial factors and the margins of trade: evidence from cross-country frim-level data. Documents de travil du Centre d'economie de la Sorbonne, 1-33.

Borghi, E., Capizzi, V., \& Zocchi, P. (2006). I servizi bancari a supporto dei processi di internazionalizzazione delle imprese: l'analisi empirica della domanda. In Onida, F. (Ed.), Internazionalizzazione e servizi finanziari per le imprese. ABI - Cespri, Bancaria editrice.

Caselli S., \& Gatti, S. (2006). Il corporate lending. Bancaria editrice.

Chiarvesio, M., Di Maria, E., \& Miceli, S. (2006). Modelli di sviluppo e strategie di internazionalizzazione in Andarsene per continuare a crescere, Carocci, Bari.

De Maeseneire, W., \& Claeys, T. (2011). SMEs, foreign direct investment and financial constraints: The case of Belgium. International Business Review, In Press.

Dunning, J.H. (1988). The eclectic paradigm of international production: a restatement and some possible extensions. Journal of international business studies, 19, 1-31. http://dx.doi.org/10.1057/palgrave.jibs.8490372

Ferri, G., De Bonis, R., \& Rotondi, Z. (2010). Do bank-firm relationships influence firm internationalization? MoFiR working paper, 37, 1-25

Filatotchev I., \& Piesse, J. (2009). R\&D, export orientation and growth of newly listed firms: European evidence. Journal of International Business Studies, 40, 1260-1276. http://dx.doi.org/10.1057/jibs.2009.18

Forssbæck, J., \& Oxelheim, L. (2008). Finance-specific factors as drivers of cross-border investment-An empirical investigation. International Business Review, 17, 630-641. http://dx.doi.org/10.1016/j.ibusrev.2008.09.001

Gottfries, N. (2002). Market shares, financial constraints, and pricing behavior in the export market. Economica, 69 , 583-607. http://dx.doi.org/10.1111/1468-0335.00302

Graves, C., \& Thomas, J. (2008). Determinants of the Internationalization Pathways of Family Firms: An Examination of Family Influence. Family Business Review, 21, 151-167. http://dx.doi.org/10.1111/j.1741-6248.2008.00119.x

Greenaway, D., Guariglia, A., \& Kneller, R. (2007). Financial factors and exporting decisions. Journal of international economics, 73, 377-395. http://dx.doi.org/10.1016/j.jinteco.2007.04.002

Knight, G., \& Cavusgil, S.T., (1996). The born global firm: a challenge to traditional internationalization theory. Advances in international marketing, 8, 11-26

Leonidou, L.C., \& Katsikeas, C.S. (1996). The export development process: an integrative review of empirical models. Journal of International Business Studies, 27, 517-551. http://dx.doi.org/10.1057/palgrave.jibs.8490846

Luostarinen, R.K. (1979). The internationalization of the firm. Helsinki: Acta Academic Oeconomicae Hesingiensis.

Madura, J., (2009). International financial management. Abridged, 9th Ed.

Maurel, C., \& Viviani, J.L. (2010). Export performance and financial constraint in French wine SMEs. 5th International Academy of Wine Business Research Conference, 8-10 Feb. 2010 Auckland (NZ).

McKinsey and co. (1993). Emerging exportrters: Australia's high value-added manufacturing exporters. Melbourne: Australian manufacturing council.

Pepe, C., \& Zucchella, A. (2009). L'internazionalizzazione delle imprese italiane, AIDEA, Il Mulino, Bologna.

Reid, S.D. (1983). Firm internationalization, transaction costs and strategic choice. International marketing review, 1 , 45-55. http://dx.doi.org/10.1108/eb008251

Remmers, L. (2004). International financial management: 35 years later-what has changed? International Business Review, 13, 155-180. http://dx.doi.org/10.1016/j.ibusrev.2003.08.003 
Sharma, D.D., \& Johanson, J. (1987). Technical consultancy in internationalization. International marketing review, 4, 20-29. http://dx.doi.org/10.1108/eb008339

Tannous, G.F. (1997). Financing export activities of small Canadian businesses: Exploring the constraints and possible solutions. International Business Review, 6, http://dx.doi.org/10.1016/S0969-5931(97)00012-7

Urionabarrenetxea, S., \& Rodríguez Castellanos, A. (2009). Decisive factors in company financial internationalization: an empirical study. Managerial Finance, $36, \quad 22-43$. http://dx.doi.org/10.1108/03074351011006829

Zahra S. A. (2003). International Expansion of U.S. Manufacturing Family Businesses: The Effect of Ownership and Involvement. Journal of Business Venturing, 18, 495-512. http://dx.doi.org/10.1016/S0883-9026(03)00057-0

\section{Note}

Note 1. A suggested study could be a deep analysis in firms that have different life cycles. 